\title{
ПИСЬМО РЕДАКТОРА
}

\section{Уважаемые читатели и авторы!}

Перед вами первый номер нового научного электронного журнала «Население и экономика».

Продолжая традиции университетской демографической школы профессора Дмитрия Игнатьевича Валентея, мы задумали сделать междисциплинарный журнал, посвященный обсуждению вопросов, связанных с населением. Предметная область исследований, результаты которых мы планируем представлять на страницах журнала, охватывает исследовательские интересы таких дисциплин, как демография, экономика народонаселения, экономика труда, социальная политика, поведенческая экономика, институциональная экономика, макроэкономика, маркетинговые исследования, социально-экономическая география, экономическая социология и другие дисциплины. Представляется, что именно на междисциплинарных перекрестках разных наук будут сделаны открытия в ближайшие десятилетия.

Журнал приветствует использование различных исследовательских методов - методов демографического анализа и прогноза, эконометрических и других математических методов, количественных и качественных социологических методов, а также методов других наук. Междисциплинарный подход предполагает взаимное использование методов разных наук.

Важной чертой современной научной действительности является небывалый рост объема информации и данных о населении. Это расширяет возможности анализа и одновременно требует создания культуры обмена данными, сформированными авторами под исследовательскую задачу, для продолжения диалога по поставленному вопросу и привлечения молодых исследователей к этому диалогу. Поэтому мы призываем авторов размещать свои рабочие базы данных и авторские коды в открытом доступе на страницах нашего журнала.

Журнал открывает разные рубрики. Помимо оригинальных статей мы будем публиковать методическую рубрику для педагогов «Трибуна преподавателя» и «Демографический календарь» о важнейших событиях и людях в мире наук о населении. В рубрике «Рецензии» мы планируем представлять наиболее обсуждаемые научные труды. Будет рубрика «Дискуссии», на страницах которой мы приглашаем ученых спорить о нерешенных теоретических вопросах и новых методах, и другие рубрики. 
Первый номер журнала предлагает вашему вниманию, уважаемые читатели, теоретические и эмпирические исследования на актуальные темы, выполненные авторами с использованием разных методов. Открыта «Трибуна преподавателя» и «Демографический календарь».

Приглашаем исследователей из разных регионов России и стран спорить, публиковать свои научные результаты, делиться созданными базами данных, методами преподавания наук о населении.

Приглашаем читателей, заинтересованных в вопросах, поднимаемых на страницах нашего журнала, к внимательному чтению, к сотрудничеству с редакцией и авторами.

Хочу пожелать всем нам полезного журнала и удовольствия от создания и чтения материалов в рубрики журнала «Население и экономика».

Ирина Е. Калабихина

Москва, МГУ, Декабрь 2017 